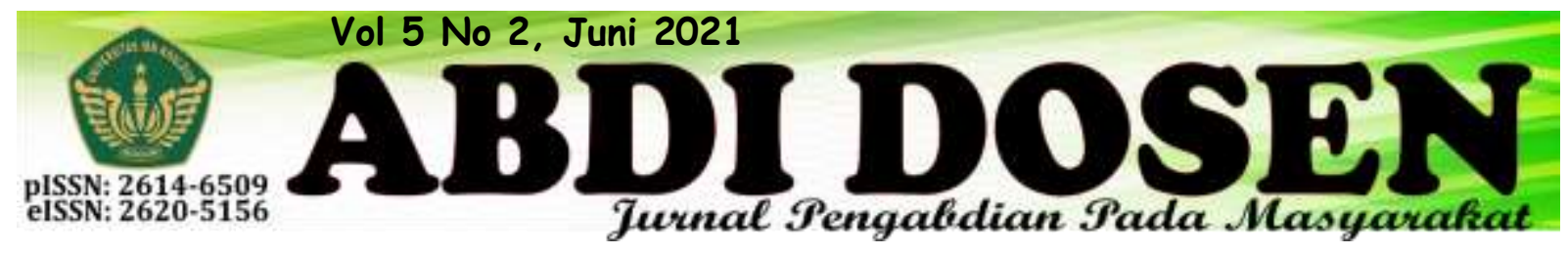

\title{
EDUKASI DETEKSI DINI KANKER PAYUDARA DAN SADARI DI POSBINDU APSARI, YOGYAKARTA
}

\author{
Resta Betaliani Wirata \\ resta@stikesbethesda.ac.id \\ Program Studi Sarjana Keperawatan, STIKES Bethesda Yakkum Yogyakarta
}

\begin{abstract}
Breast cancer problem is still a special challenge for women of childbearing age in Indonesia. Prevention promoted in Indonesia is by doing BSE (Self Check Breast). RW 10 Bumijo, Jetis, Yogykarta has formed a special Posbindu for women of childbearing age under the name Posbindu Apsari. Posbindu Apsari management tries to get information related to women's health to improve the health quality of women, one of which is about breast cancer. The purpose of this activity was to find out the knowledge before and after breast cancer health education and BSE in women of childbearing age in Porbindu Apsari. The method used is the One Groups Pretest-Posttest Design. The number of samples was 23 people who were taken using an accidental sampling technique. The results of the evaluation of knowledge showed that there was a significant increase in breast cancer and BSE knowledge after counseling which was indicated by the p-value of $0.000<\alpha 0.05$. The importance of breast cancer counseling and BSE activities using media and evaluation with the pre-post test to increase knowledge of women of childbearing age.
\end{abstract}

\section{Keywords: Breast Cancer, Breast Self-Examination, Childbearing age, Health Education}

\begin{abstract}
ABSTRAK
Masalah mengenai kanker payudara masih menjadi tantangan khusus bagi wanita usia subur di Indonesia. Pencegahan yang digalangkan di Indonesia adalah dengan melakukan SADARI (Periksa Payudara Sendiri). RW 10 Bumijo, Jetis, Yogykarta telah membentuk Posbindu khusus wanita usia subur dengan nama Posbindu Apsari. Pengurus Posbindu Apsari berusaha mendapatkan informasi terkait kesehatan wanita untuk meningkatkan kualiats kesehatan wanita usia subur, salah satunya mengenai kanker payudara. Tujuan kegiatan ini untuk mengetahui pengetahuan sebelum dan sesudah penyuluhan kanker payudara dan SADARI pada wanita usia subur di Porbindu Apsari. Metode yang dilakukan dengan One Groups Pretest-Posttest Design. Jumlah sampel sebanyak 23 orang yang diambil dengan teknik accidental sampling. Hasil evaluasi pengetahuan menunjukkan adanya peningkatan pengetahuan kanker payudara dan SADARI setelah dilakukan penyuluhan secara signifikan yang ditunjukkan dari hasil p-value $0.000<\alpha 0.05$. Pentingnya kegiatan penyuluhan kanker payudara dan SADARI menggunakan media yang baik dan dilakukan evaluasi dengan prepost test untuk meningkatkan pengetahuan wanita usia subur.
\end{abstract}

Kata kunci: Kanker Payudara, SADARI, Usia Subur, Pendidikan Kesehatan 


\section{PENDAHULUAN}

Masalah mengenai kanker payudara masih menjadi tantangan khusus bagi wanita usia subur di Indonesia. Banyak penelitian yang telah dilakukan mengenai penyakit kanker payudara ini, namun belum dapat menghentikan kemunculan kanker payudara. Pada bulan Januari 2019, jumlah kumulatif penderita kanker payudara di Indonesia yang dilaporkan KemenKes mencapai 42,1 per 100.000 penduduk, dan paling banyak ditemukan pada usia 30-50 tahun (Komite Penanggulangan Kanker Nasional, 2015).

Kanker adalah penyakit tidak menular yang ditandai dengan pertumbuhan sel tidak normal dan terusmenerus, serta tidak terkendali yang dapat merusak jaringan sekitarnya dan dapat menjalar ke tempat yang lebih jauh dari asalnya yang disebut metastase. Fase awal kanker payudara adalah asimtomatik atau tanpa tanda dan gejala. Adanya benjolan atau penebalan pada payudara merupakan tanda atau gejala awal yang paling umum terjadi (Arafah \& Notobroto, 2017).

Tanda dan gelaja lebih lanjut dari kanker payudara yaitu adanya kulit cekung, retraksi atau deviasi putting susu dan rasa nyeri, nyeri tekan dan adanya cairan yang keluar dari putting, Kulit tebal dengan pori-pori menonjol sama dengan kulit jeruk dana tau ulserasi pada payudara (Arsittasari et al., 2017). Kanker yang sudah menjalar kebagian lain tubuh atau metastase menimbulkan tanda dan gejala anoreksia, berat badan menurun, nyeri pada bahu, pinggang, punggung bagian bawah atau pelvis, gangguan pencernaan, pusing, penglihatan kabur dan sakit kepala (Sander, 2012).

Di Indonesia kanker payudara lebih banyak menyerang wanita dari pada pria (Komite Penanggulangan Kanker
Nasional, 2015). Sekitar 70\% penderita kanker payudara datang ke Rumah Sakit dengan kondisi sudah dalam stadium lanjut (Despitasari, 2017). Pencegahan kanker payudara dilakukan lebih awal sebelum tanda dan gejala itu muncul atau terasa. Pencegahan yang digalangkan di Indonesia adalah dengan melakukan SADARI (Periksa Payudara Sendiri).

Pemeriksaan SADARI dilakukan setiap kali selesai menstruasi yaitu hari ke7 sampai hari ke-10 terhitung hari pertama menstruasi, karena pada saat setelah menstruasi selesai pengaruh hormon estrogen dan progesterone sangat rendah dan kelenjar jaringan payudara saat itu tidak membengkak sehingga lebih mudah meraba adanya tumor atau pun kelainan pada payudara. SADARI dilakukan sebagai salah satu metode deteksi dini untuk menemukan kanker payudara stadium awal yang lebih efektif bila dilakukan sedini mungkin (Komite Penanggulangan Kanker Nasional, 2015).

RW 10 Bumijo, Jetis, Yogykarta telah membentuk Posbindu khusus wanita usia subur dengan nama Posbindu Apsari. Dasar pembentukan Posbindu kesehatan wanita usia subur ini dikarenakan rasa empati para ibu-ibu melihat wanita usia subur di wilayah RW 10 Bumijo, Jetis, Yogyakarta mendapatkan kualitas kesehatan yang baik. Kegiatan posbindu kesehatan wanita usia subur ini secara rutin dilakukan sekali setiap bulan.

SADARI perlu dilakukan secara benar dan rutin. Gerakan SADARI pun sangat mudah, namun walau pun mudah masih banyak wanita usia subur yang belum melakukan deteksi dini mandiri tersebut. Pengetahuan yang kurang dari wanita usia subur di posbindu APSARI mengenai kanker payudara dan SADARI 
menjadi tempat yang baik untuk dilakukan pemberian edukasi tentang kanker payudara dan SADARI.

\section{METODE PELAKSANAAN}

Untuk mencapai tujuan dan target yang diharapkan, kegiatan yang dilaksanakan adalah dengan melaksanakan penyuluhan mengenai Penyakit Kanker Payudara dan SADARI, meliputi pengertian kanker, cara merawat kesehatan payudara, kapan melakukan SADARI, gejala dan tanda kanker payudara, dan prosedur SADARI. Penyuluhan diberikan oleh pelaksana PkM bersama-sama dengan asisten PkM yaitu mahasiswa dan didampingi Ketua RW 10 Bumijo dengan media powerpoint. Pre-test dilakukan sebelum dan Post-test dilakukan sesudah kegiatan untuk mengetahui peningkatan pengetahuan wanita usia subur terhadap materi yang sudah disampaikan. Pre test dan post test dilaksanakan sebelum dan sesudah kegiatan untuk mengetahui

\section{HASIL dan PEMBAHASAN}

Kegiatan pengabdian masyarakat ini diikuti oleh 23 orang anggota dari posbindu APSARI. Kegiatan penyuluhan mengenai penyakit kanker payudara dan SADARI ini berjalan secara lancar. Program penyuluhan ini sudah dilakukan secara continue sesuai dengan kebutuhan yang diperlukan oleh sasaran atau anggota posbindu APSARI.

Pihak ketua PKK RW 10 Bumijo memberikan apresiasi pada kegiatan ini, dimana pentingnya pengetahuan terkait kanker payudara yang mengincar wanita usia subur dan SADARI yang dapat digunakan untuk mencegah sedini mungkin akan kemunculan awal dari kanker payudara, sehingga dapat peningkatan pengetahuan terhadap materi yang telah disampaikan (Kamila \& Ismail, 2020).

Desain metode yang digunakan adalah dengan One Groups Pretest-Posttest Design. One Groups Pretest-Posttest Design yaitu variable diukur terlebih dahulu sebelum diberikan perlakuan (pretest) setelah itu dilakukan perlakuan dan dilakukan pengukuran diakhir (post-test) (Nita \& Inrayani, 2020). Populasi kegiatan ini adalah seluruh anggota Posbindu Apsari yang hadir saat penyuluhan yaitu wanita usia subur. Pengambilan sampel dengan teknik accidental sampling yang berjumlah 23 orang. Pengambilan data dilakukan menggunakan kuesioner dan dikumpulkan, kemudian dianalisa menggunakan uji paired t-test.

menurunkan angka morbiditas dan mortalitas wanita dengan kanker payudara.

Sebelum melakukan penyuluhan, pelaksana dibantu asisten $\mathrm{PkM}$ terlebih dahulu melakukan pengukuran tekanan darah dan membagikan soal pre-test kepada seluruh anggota posbindu APSARI yang hadir sesuai dengan teknik accidental sampling yang dipilih dalam kegiatan ini. Setelah semua peserta masuk ke dalam ruang penyuluhan, kegiatan dibuka dengan sambutan dari ketua PKK RW 10 Bumijo dan dilanjutkan kepada kegiatan inti. Pada kegiatan inti, yaitu penyuluhan, pelaksana PkM memaparkan mengenai Kanker Payudara dan SADARI yang terdiri dari: (1) Pengertian Kanker; (2) Cara Merawat 
Kesehatan Payudara; (3) Kapan Melakukan SADARI; (4) Gejala dan Tanda Kanker Payudara; dan (7) Prosedur SADARI.

Wanita usia subur perlu mengetahui mengenai kanker payudara untuk menekankan informasi yang benar mengenai kanker yang menyerang payudara yang dapat menyebabkan kematian. Dengan informasi yang benar diharapkan wanita usia subur akan memiliki sikap dan perilaku yang bertanggung jawab sesuai dengan kesehatan mereka. Prosedur SADARI sangat perlu disampaikan kepada wanita usia subur, sebagai panduan dan acuan dalam melakukan SADARI di rumah serta dapat dilakukan dengan benar dan rutin untuk mendeteksi kanker payudara sejak awal. Wanita usia subur perlu diberikan informasi mengenai prosedur SADARI, sehingga wanita usia subur dapat melakukan SADARI sejak awal dan dilakukan rutin dengan benar untuk melindungi dan mencegah diri mereka sendiri dari ancaman kanker payudara. Peningkatan pemahaman pada orang lain dapat terjadi setelah diberikan informasi atau wawasan secara langsung (Yetti, 2018).

Penyampaian materi ini dilakukan dengan media powerpoint. Efektivitas pemberian materi melalui powerpoint berpengaruh terhadap peningkatan pengetahuan bagi sasaran. Sejalan dengan penelitian yang telah dilakukan oleh Fitriana dan Apriani pada tahun 2019 bahwa dengan media powerpoint dalam memberikan informasi dapat meningkatkan pengetahuan pada sasaran. Media powerpoint merupakan media yang tergolong dalam kelompok gambar diam yang memiliki kemampuan untuk merangsang penerima informasi memahami materi yang disampaikan (Fitriana \& Apriani, 2019).

Efektivitas penyuluhan kepada masyarakat yang diberikan kepada pelaksana $\mathrm{PkM}$ memberikan dampak positif bagi sasaran atau memberikan perubahan pengetahuan. Promosi kesehatan dengan penyuluhan menggunakan media teknologi informasi sangat membantu dalam tercapainya target penyuluhan yaitu untuk meningkatkan pengetahuan penerima promosi kesehatan (Studi et al., 2016). Hal ini sesuai dengan hasil evaluasi penyuluhan kanker payudara dan SADARI yang dapat dilihat melalui hasil nilai pre-test dan post-test. Distribusi frekuensi dapat ditunjukkan pada table sebagai berikut:

Tabel 1. Perbedaan Tingkat Pengetahuan Sebelum dan Sesudah Penyuluhan

\begin{tabular}{cccc}
\hline & \multicolumn{3}{c}{ Hasil } \\
\cline { 2 - 4 } Tingkat & Pre-Test & Post-Test & p-value \\
\hline Cukup & 19 & 0 & \\
Tinggi & 4 & 23 & 0.000 \\
Mean & 0.17 & 1.00 & \\
Total & 23 & 23 & \\
*Uji Paired T-test & &
\end{tabular}

Hasil pada table diatas menunjukkan bahwa ada peningkatan pengetahuan yang signifikan dari hasil pre-test dan post-test yang diberikan sebelum dan sesudah penyuluhan dilaksanakan. Hasil pengetahuan mengenai kanker payudara 
dan SADARI pada wanita usia subur menunjukkan pada pre-test terdapat 19 wanita usia subur dengan pengetahuan cukup dan 4 orang dengan pengetahuan tinggi. Sedangkan hasil post-test menunjukkan 23 wanita usia subur memiliki pengetahuan tinggi. Sehingga adanya peningkatan pengetahuan terkait hasil penyuluhan atau kegiatan PkM. Hasil mean menunjukkan hasil pre-test < posttest yang artinya terdapat peningkatan ratarata pengetahuan pada sasaran. Nilai $p$ value 0.000 yaitu kurang dari $\alpha 0.05$ sehingga terdapat pengaruh penyuluhan terhadap pengetahuan secara signifikan. Hasil studi mengenai pendidikan kesehatan SADARI terhadap pengetahuan dan sikap wanita usia produktif akan lebih menyadarkan betapa pentingnya pemeriksaan payudara sendiri dilakukan. Sehingga pentingnya memunculkan kesadaran wanita usia produktif mengenai SADARI untuk mencegah terjadinya kanker payudara sedini mungkin dapat dilakukan dengan melaksanakan pendidikan kesehatan (Purba \& Simanjuntak, 2019).

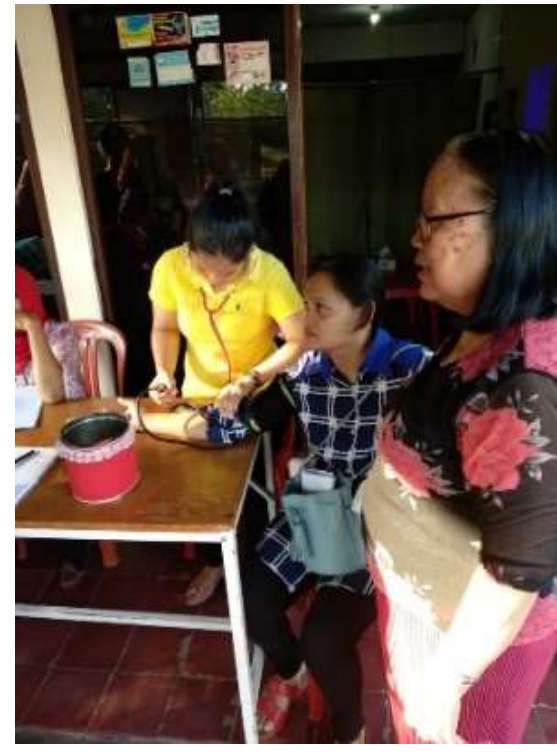

Gambar. 1 Pengukuran

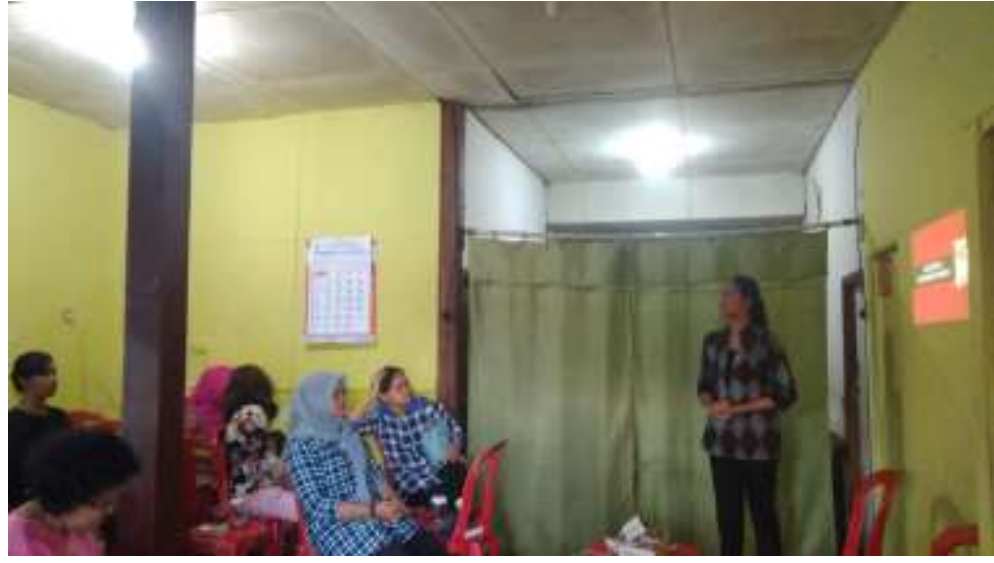

Gambar 2. Penyuluhan Kanker Payudara dan SADARI

Tekanan Darah oleh asisten

PKM (mahasiswa)

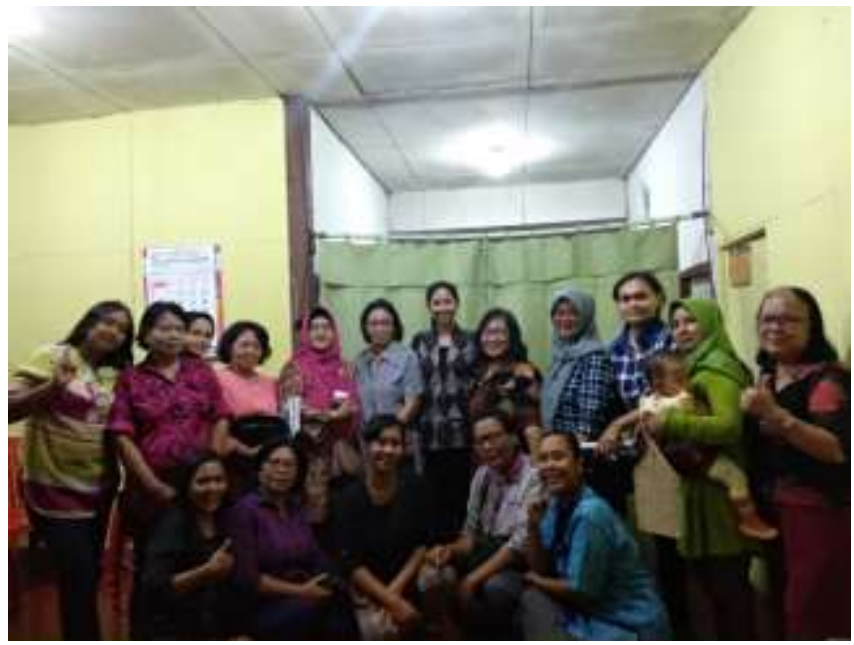

Gambar 3. Pelaksanaan PKM bersama Pengurus Posbindu Apsari 


\section{KESIMPULAN}

Kesimpulan dari kegiatan pengabdian masyarakat yang telah dilakukan dapat disimpulkan bahwa pengetahuan yang benar dan tepat tentang penyakit Kanker Payudara dan SADARI merupakan salah satu hal penting dalam rangka menyadarkan wanita usia subur mendeteksi kanker payudara sedini mungkin dan dapat dilakukan secara

\section{DAFTAR PUSTAKA}

Arafah, A. B. R., \& Notobroto, H. B. (2017). Faktor Yang Berhubungan Dengan Perilaku Ibu Rumah Tangga Melakukan Pemeriksaan Payudara Sendiri (SADARI) Alvita Brilliana R. Arafah, Hari Basuki Notobroto. Ijph, 12(August), 143-153. https://doi.org/10.20473/ijph.v12i1.2 $\underline{017.143-153}$

Arsittasari, T., Estiwidani, D., \& Setiyawati, N. (2017). Faktor-Faktor Yang Berhubungan Dengan Kejadian Kanker Payudara Di Rsud Kota Yogyakarta Tahun 2016. Jurnal Kebidanan.

Despitasari, L. (2017). Hubungan Dukungan Keluarga dan Pemeriksaan Payudara Sendiri (SADARI) dengan Keterlambatan Pemeriksaan Kanker Payudara Pada Penderita Kanker Payudara di Poli Bedah RSUP DR. M. Djamil Padang. Jurnal Keperawatan Muhammadiyah, 2 (1). https://doi.or $\mathrm{g} / 10.30651 / \mathrm{jkm} . \mathrm{v} 2 \mathrm{i} 1.1110$

Fitriana, L. B., \& Apriani, W. R. (2019). Studi Komparatif Pengetahuan Orang Tua Tentang Temper Tantrum benar dan rutin. Kegiatan penyuluhan ini berhasil meningkatkan pengetahuan wanita usia subur secara signifikan sesuai dengan hasil evaluasi kegiatan penyuluhan. Diharapkan tidak hanya pengetahuan saja yang berubah namun dapat meningkatkan perilaku yang dapat dilakukan oleh setiap anggota posbindu APSARI.

\section{yang Diberikan Pendidikan Kesehatan dengan Media Power Point dan Flip Chart. Jurnal ILKES (Jurnal Ilmu Kesehatan), 10(1), 16- 24. \\ https://doi.org/https://doi.org/10.359 66/ilkes.v10i1.108.}

Kamila, A., \& Ismail, A. (2020). Edukasi HIV / AIDS "Gerakan 1000 Remaja Millenial Peduli Odha " ( Gerserha ) di MA Al-Mukhtariyah Kabupaten Bandung Barat. DINAMISIA: Jurnal Pengabdian Kepada Masyarakat, 4(2), 201-208.

Komite Penanggulangan Kanker Nasional. (2015). Panduan Penatalaksanaan Kanker Payudara. Kementerian Kesehatan Republik Indonesia, 1, 12 $-14,24-26,45$.

https://doi.org/10.1111/evo.12990

Nita, V., \& Inrayani, N. (2020). Pendidikan Kesehatan Dalam Upaya Pencegahan Kanker Serviks Pada Wanita Usia Subur. DINAMISIA: Jurnal Pengabdian Kepada Masyarakat, 4 (2), 306-310.

Purba, A. E. T., \& Simanjuntak, E. H. 
(2019). Efektivitas Pendidikan Kesehatan Sadari terhadap Peningkatan Pengetahuan dan Sikap Wus tentang Deteksi Dini Kanker Payudara. Jurnal Bidan Komunitas, 2(3), 160. https://doi.org/10.33085/jb k.v2i3.4476

Sander, M. A. (2012). Profil Penderita Kanker Payudara Stadium Lanjut Baik Lokal Maupun Metastasis Jauh Di Rsup Hasan Sadikin Bandung. Farmasains: Jurnal Farmasi Dan Ilmu Kesehatan, 1(2). https://doi.org/ $\underline{10.22219 / \text { far.v1i2.1168 }}$
Studi, P., Pendidik, B., Diploma, J., \& Kesehatan, F. I. (2016). Media Power Point Dan Video Terhadap.

Yetti, Y. (2018). Peningkatan Pemahaman Masyarakat Desa Batang Kulim Kecamatan Pangkalan Kuras Kabupaten Pelalawan Mengenai Undang-Undang Nomor 16 Tahun 2011 Tentang Bantuan Hukum. Dinamisia : Jurnal Pengabdian Kepada Masyarakat, 2(2), 240-246. https://doi.org/10.31849/dinamisia.v $\underline{2 \mathrm{i} 2.1473}$ 